\title{
Antibacterial activity of Costus pulverulentus (Costaceae) C. Presl
}

\section{Actividad antibacteriana de Costus pulverulentus (Costaceae) C. Presl}

RAMIRO-BAUTISTA, Luis Rodrigo $\dagger$, HERNÁNDEZ-MORALES, Alejandro*, CARRANZAÁLVAREZ, Candy and MALDONADO-MIRANDA, Juan José

Universidad Autónoma de San Luis Potosí, Facultad de Estudios Profesionales Zona Huasteca. Romualdo del Campo 501, Fraccionamiento Rafael Curiel, CP 79060, Ciudad Valles San Luis Potosí, México.

ID $1^{\text {st }}$ Author: Luis Rodrigo, Ramiro-Bautista / ORC ID: 0000-0002-6495-3324, Researcher ID Thomson: ABE-3264-2020, CVU CONACYT: 787136

ID $1^{\text {st }}$ Coauthor: Alejandro, Hernández-Morales / ORC ID: 0000-0002-0412-4946, Researcher ID Thomson: P-8441-2014, CVU CONACYT ID: 101590

ID $2^{\text {nd }}$ Coauthor: Candy, Carranza-Álvarez / ORC ID: 0000-0002-6456-3035, CVU CONACYT ID: 43169

ID $3^{\text {rd }}$ Coauthor: Juan José, Maldonado-Miranda / ORC ID: 0000-0003-2905-9914, CVU CONACYT ID: 390832

DOI: $10.35429 / J N A S .2020 .20 .7 .1 .13$

Received March 21, 2020; Accepted June 30, 2020

Abstract

Antimicrobial resistance is a great concern in public health Therefore, it is necessary to obtain new compounds to treat diseases caused by bacteria. Medicinal plants are an alternative to search natural compounds to improve human health, including antioxidants, anti-inflammatory, and antimicrobials compounds. Costus pulverulentus (Costaceae) C. Presl is a plant used traditionally in Huasteca Potosina to treat bacterial infections. However, the compounds involved in this activity remain poorly understood. To determine the antibacterial activity of $C$. pulverulentus, an ethanolic extract was obtained. Plant stem was macerated in ethanol and then was fractionated with hexane, chloroform, ethyl acetate, acetone, ethanol, and methanol. Ethanolic extract and derived fractions were tested against bacteria by the disk-diffusion agar method. The results showed that the ethanolic extract of C. pulverulentus exerted activity against Chromobacterium violaceum CV026 and Bacillus sp. at 10 and $30 \mu \mathrm{g} / \mathrm{disk}$, whereas only the methanolic fraction showed similar activity to complete extract. Fraction 8 obtained from methanolic fraction showed inhibitory activity against Bacillus sp., $S$. aureus, and $S$. aureus Oxacillin resistant. Gas Chromatography-Mass Spectrometry characterization of active fraction 8 showed that it contains vanillic acid and pcoumaric acid suggesting that they are involved in the antibacterial activity of $C$. pulverulentus.

Antimicrobials, Costus pulverulentus, p-coumaric acid

\section{Resumen}

La resistencia a los antimicrobianos es una gran preocupación en la salud pública. Por tanto, es necesario obtener nuevos compuestos para tratar enfermedades provocadas por bacterias. Las plantas medicinales son una alternativa para buscar compuestos naturales para mejorar la salud humana, incluidos compuestos antioxidantes, antiinflamatorios y antimicrobianos. Costus pulverulentus (Costaceae) C. Presl es una planta utilizada tradicionalmente en la Huasteca Potosina para tratar infecciones bacterianas. Sin embargo, los compuestos implicados en esta actividad siguen siendo poco conocidos. Para determinar la actividad antibacteriana de $C$. pulverulentus se obtuvo un extracto etanólico. El tallo de la planta se maceró en etanol y luego se fraccionó con hexano, cloroformo, acetato de etilo, acetona, etanol y metanol. El extracto etanólico y las fracciones derivadas se probaron contra bacterias mediante el método de agar de difusión en disco. Los resultados mostraron que el extracto etanólico de C. pulverulentus ejerció actividad contra Chromobacterium violaceum CV026 y Bacillus sp. a 10 y $30 \mu \mathrm{g} /$ disco, mientras que solo la fracción metanólica mostró una actividad similar al extracto completo. La fracción 8 obtenida a partir de la fracción metanólica mostró actividad inhibidora frente a Bacillus sp., S. aureus y $S$. aureus resistente a oxacilina. La caracterización por cromatografía de gases y espectrometría de masas de la fracción activa 8 mostró que contiene ácido vainílico y ácido $p$-cumárico, lo que sugiere que están involucrados en la actividad antibacteriana de $C$. pulverulentus.

Antimicrobianos, Costus pulverulentus, Ácido p-cumárico

Citacion: RAMIRO-BAUTISTA, Luis Rodrigo, HERNÁNDEZ-MORALES, Alejandro, CARRANZA-ÁLVAREZ, Candy and MALDONADO-MIRANDA, Juan José. Antibacterial activity of Costus pulverulentus (Costaceae) C. Presl. Journal of Natural and Agricultural Sciences. 2020, 7-20: 1-13

\footnotetext{
* Correspondence to Author (email: alejandro.hernandez@uaslp.mx)

$\dagger$ Researcher contributing first author.
} 


\section{Introduction}

Currently there is a huge and serious problem caused by the increase in the resistance of microorganisms to antimicrobial treatments. Resistance occurs when microorganisms undergo changes that make the drugs used to cure infections stop being effective, as a result, infections persist in the body, increasing the risk of spreading to other people (WHO, 2017). This represents one of the greatest threats to global health, food security and development. In addition, it jeopardizes the medical capacity to treat common infectious diseases, with the consequent increase in hospital stays, deaths, and the prolongation of the disease and with it medical costs (WHO, 2016).

Among the resistant microorganisms with a wider distribution and that represent a serious health problem because they are important etiological agents of infections of the urogenital and gastrointestinal tract are: the nonencapsulated enterobacterium Escherichia coli, the encapsulated enterobacterium Klebsiella pneumoniae, the Gram-positive cocci Staphylococcus aureus, the non-relevant enterobacterium Pseudomonas aeruginosa, parasites such as Entamoeba histolytica, and yeast fungi such as Candida albicans (Cohen and Tartasky, 1997; Bansal, Malla, and Mahajan, 2006; Calderon and Aguilar, 2016).

The problem becomes more relevant when it is considered that most of the countries worldwide, mainly those in the developing world, do not have one hundred percent guaranteed access to health services, for which strategies based on traditional medicine are sought and complementary (MTC), among which the use of medicinal plants stands out (WHO, 2013).

In Huasteca Potosina, the enormous existing biodiversity makes it possible to have a great variety of therapeutic herbal resources both in rural and suburban areas (Alonso-Castro, et al., 2015). Research has been carried out on some plants, among them Costus pulverulentus stands out for the ethnopharmacological applications that are given to it (treatment of infections of the urinary and gastrointestinal system) and the studies previously carried out that showed various beneficial effects of the plant.
However, validation tests are still lacking for different activities assigned to $C$. pulverulentus, among them is the antibacterial capacity, which is suggested derived from phytochemical studies previously carried out in which compounds reported with this effect were found. Therefore, this study evaluated the antimicrobial effect on bacteria of clinical importance of the complete ethanolic extract and organic fractions obtained from $C$. pulverulentus (Costaceae) as well as the identification of the bioactive metabolite.

\section{Methodology}

\section{Vegetal material}

The plants were collected in August 2017 in Ciudad Valles, San Luis Potosí at coordinates 21 ○ 49'39.4 "N $999^{\circ} 05^{\prime} 18.9^{\prime}$ W. A specimen with collection number SLPM-033070 was deposited in the Herbarium Isidro Palacios Desert Zones Research Institute, Autonomous University of San Luis Potosí.

\section{Preparation of the ethanolic extract (E.E)}

$100 \mathrm{~g}$ of powdered dried stem were macerated in $1000 \mathrm{~mL}$ of ethanol for seven days in the dark. The extract was filtered and concentrated to dryness on the R-100 rotary evaporator (Büchi). The dry residue was fractionated into hexane, chloroform, ethyl acetate, acetone, ethanol, and methanol. Subsequently, the active fraction was separated by column chromatography packed with Silica gel 70-230 mesh, 63-200 $\mu \mathrm{m}$ (Sigma 60741) using a solvent system hexane: ethyl acetate: methanol in increasing polarity.

\section{Fractionation of the extract}

The E.E. It was fractionated using ACS grade solvents of different polarity starting from lowest to highest, hexane <chloroform <ethyl acetate <acetone <ethanol <methanol. The dry residue of E.E. It was dissolved in $50 \mathrm{ml}$ of hexane, two fractions were obtained, soluble and insoluble. The soluble fraction was recovered and brought to dryness in the convection oven. The dry residue was weighed to determine the yield, subsequently it was dissolved in absolute ethanol and the concentration was calculated in $\mathrm{mg} / \mathrm{mL}$. 
On the other hand, the fraction insoluble in hexane (residue) was brought to total dryness at $45^{\circ} \mathrm{C}$ for $48 \mathrm{~h}$ and dissolved in chloroform, again two fractions (soluble and insoluble) were obtained. The soluble fraction was recovered and dried in the convection oven and weighed to calculate the yield. The chloroform fraction was dissolved in absolute ethanol and the concentration was calculated in $\mathrm{mg} / \mathrm{mL}$. The same procedure was repeated with each of the remaining solvents, thus obtaining a total of six fractions of known concentration in $\mathrm{mg} / \mathrm{mL}$.

\section{Column chromatography}

A 22 x $450 \mathrm{~mm}$ glass column was used, packed with a suspension of $21.5 \mathrm{~g}$ of Silica Gel 70-230 mesh, 63-200 $\mu \mathrm{m}$ (Sigma 60741) in $100 \mathrm{~mL}$ of hexane. The column was allowed to stand for one hour at room temperature and was subsequently loaded with $250 \mathrm{mg}$ of the sample. The mobile phase consisted of the polarity gradient solvent system formed by Hex: AceOEt: $\mathrm{MeOH}$ (Table 1). The resolution of the sample was carried out with a flow of 60 drops / min. $50 \mathrm{ml}$ fractions were collected, which were concentrated using the Rotavapor R-100 (Büchi).

\begin{tabular}{|r|r|r|}
\hline $\begin{array}{c}\text { Hexane } \\
\text { (ml) }\end{array}$ & $\begin{array}{c}\text { Ethyl acetate } \\
\text { (ml) }\end{array}$ & $\begin{array}{c}\text { Methanol } \\
\text { (ml) }\end{array}$ \\
\hline 100 & 0 & 0 \\
\hline 90 & 10 & 0 \\
\hline 80 & 20 & 0.1 \\
\hline 70 & 30 & 0.2 \\
\hline 60 & 40 & 0.3 \\
\hline 50 & 50 & 0.4 \\
\hline 40 & 60 & 0.5 \\
\hline 30 & 70 & 0.6 \\
\hline 20 & 80 & 0.7 \\
\hline 10 & 90 & 0.8 \\
\hline 0 & 100 & 0.9 \\
\hline
\end{tabular}

Table 1 Solvent system used in Column Chromatography

\section{Gas Chromatography coupled to Mass Spectrometry}

The extracts and organic fractions were derivatized using the following methodology. 50 $\mu \mathrm{L}$ of extract was dried under a nitrogen flow. Subsequently, $20 \mu \mathrm{L}$ of pyridine (Sigma 270407 ) and $80 \mu \mathrm{L}$ of BSTFA reagent with $1 \%$ TMCS (Sigma 15238) were added and incubated at $85^{\circ} \mathrm{C}$ for $25 \mathrm{~min}$. The reaction mixture was cooled to room temperature, Isooctane (Sigma 650439 ) was added to a final volume of $200 \mu 1$.
Finally, $100 \mu \mathrm{L}$ of the clear mixture was transferred to a vial and analyzed by GC-MS. For the analysis, a Gas Chromatograph model GC9090A (Agilent Technologies) coupled to a mass spectrometer model 5975 (Agilent Technologies) was used. $1 \mu \mathrm{L}$ of the derivatized was analyzed in pulsed split injection mode with a ratio of 5: 1 . The injector temperature was 250 ${ }^{\circ} \mathrm{C}$. Chromatographic separation was performed on an Agilent J\&W DB-1MSUI capillary column $(60 \mathrm{~m}$ x $250 \mu \mathrm{m}$ x $0.25 \mu \mathrm{m})$ and helium was used as carrier gas at a constant flow rate of $1 \mathrm{~mL} / \mathrm{min}$. The GC oven program started at an initial temperature of $45^{\circ} \mathrm{C}$, was maintained for 5 minutes and then increased at a rate of $10^{\circ} \mathrm{C}$ per minute until a final temperature of $300^{\circ} \mathrm{C}$ was obtained, which was maintained for 25 minutes.

The temperature of the transfer line was adjusted to $250^{\circ} \mathrm{C}$. Mass spectra were obtained at $70 \mathrm{eV}$ electron energy. Measurements were made in scan mode with a $\mathrm{m} / \mathrm{z}$ range set to 40 550. The ion source and the temperature of the quadrupole analyzer were $230{ }^{\circ} \mathrm{C}$ and $150{ }^{\circ} \mathrm{C}$ respectively, they kept running at 2.9 scans per second.

Data obtained by GC-EM were examined with MassHunter Workstation software version B.06.00 (Agilent Technologies). The AMDIS software (http://www.amdis.net/) was used for the determination of the retention time and the extraction of the mass spectrum of each component of the chromatograms. The mass spectral library software and the NIST MS database were used for the identification of compounds.

\section{Determination of antimicrobial activity}

\section{Microorganisms}

Five Gram positive bacteria Staphylococcus epidermidis, Staphylococcus aureus, S. aureus OxR, Enterococcus faecalis, Bacillus sp. and five Gram negative bacteria Escherichia coli, Pseudomonas aeruginosa, Klebsiella pneumoniae, Aeromonas hydrophila, Proteus mirabilis, Citrobacter freundii, Chromobacterium violaceum CV026. 


\section{Disk diffusion test}

10 and $30 \mu \mathrm{g}$ of ethanolic extract, organic fractions were placed on sterile filter paper disks. Subsequently, the discs were placed on a bacterial lawn inoculated on Mueller Hinton Agar (MH) plates, left to rest at $4^{\circ} \mathrm{C}$ for one hour and subsequently incubated at $37^{\circ} \mathrm{C}$ for $24 \mathrm{~h}$. After the incubation time, the diameter of the inhibition halos generated by the evaluated extracts was measured. Three replications were performed per treatment, and the experiments were repeated three times.

\section{Determination of the Minimum Inhibitory Concentration}

The M100 protocol proposed by the CLSI (Coyle, 2005) and the guidelines established by Cos et al. (2006) and Balouiri (2016) were used. The plate microdilution method was used, for this, the compound solution to be evaluated was diluted 1: 2 in Mueller Hinton broth. The wells were inoculated with a bacterial suspension at turbidity equivalent to the McFarland standard 0.5 to have $1 \times 10^{8} \mathrm{CFU} / \mathrm{mL}$ in each well of the microplate (Cos, et al., 2006; Balouiri, et al., 2016). The plate was incubated at $37^{\circ} \mathrm{C}$ for 24 $\mathrm{h}$ and subsequently visually inspected. The lowest dilution of the compound where no microbial growth was observed was considered the minimum inhibitory concentration (MIC). To check MIC, $5 \mu \mathrm{l}$ of a $0.05 \%$ tetrazolium chloride indicator solution was added to each well. Wells where the reduction of tetrazolium chloride was not observed indicated absence of microbial activity.

\section{Anti Quorum sensing activity}

Chromobacterium violaceum CV026 was inoculated in LB broth supplemented with Kanamycin $(100 \mu \mathrm{g} / \mathrm{mL})$ and incubated at 30 ${ }^{\circ} \mathrm{C}$ for $24 \mathrm{~h}$. Subsequently, $500 \mu \mathrm{l}$ of the culture was mixed with $100 \mathrm{ml}$ of LB agar melted at 45

○ C supplemented with Kanamycin (100 $\mu \mathrm{g}$ / $\mathrm{mL})$ and $1 \mu \mathrm{M}$ of N-butanoyl-1-homoserine lactone (C4-HSL). The mixture was poured into Petri dishes and gently shaken for uniform distribution. For the anti quorum sensing activity, discs were placed on the surface of the agar impregnated with Ethanolic Extract and organic fractions. The absence of purple pigmentation in $C$. violaceum $\mathrm{CV} 026$ colonies indicates anti quorum activity.
The appearance of colonies with purple pigment indicates that the extracts and fractions lack activity

\section{Determination of toxicity with Artemia salina}

Eggs of A. salina were hatched in artificial seawater, incubated at $28^{\circ} \mathrm{C}$ for $24 \mathrm{~h}$, placed under a yellow light lamp and fed fish diet. To evaluate the toxicity, 20 nauplii of $A$. salina were placed in a plastic container and the doses of extracts, methanolic fraction and F8, etc. were added. The tests were incubated under the same conditions and mortality was determined at $24 \mathrm{~h}$. Three repetitions were performed per treatment and the experiment was repeated three times (Rajabi, et al., 2015)

\section{Results}

\section{Preparation of the ethanolic extract of $\mathrm{C}$. pulverulentus}

From $100 \mathrm{~g}$ of fresh plant, $7.86 \pm 0.77 \mathrm{~g}$ of dry ground plant were recovered, which was macerated in ethanol to obtain the ethanolic extract. $0.39 \pm 0.01 \mathrm{~g}$ of dry ethanolic extract were obtained, which corresponds to $5.10 \pm$ $0.58 \%$ of yield based on the dry weight of the plant. The extract was analyzed by GC-MS and 94 peaks were detected, 74 peaks $(79 \%)$ were identified in the NIST database, while 20 peaks (21\%) did not show similarity with reported compounds.

Most of the compounds identified in the extract correspond to carbohydrates, organic acids and sterols. The most abundant compound in the ethanolic extract of $C$. pulverulentus was D-psychofuranose with a retention time (RT) of $26.46 \mathrm{~m}$ and relative abundance of $9.74 \%$ (Table 3 , while, among the organic acids, the phydroxy-cinnamic with TR of 27.41 was the most abundant with a relative abundance of $6.79 \%$.

This compound has been previously reported in ethanolic extract of $C$. pulverulentus in $7.38 \%$ (Alonso-Castro et al. 2016). Hydroxycinnamic acid is a phenolic compound that acts as an antioxidant and inhibitor of the action of free radicals. It is found in a wide variety of vegetables, fruits, and grains; and it presents antioxidant, antimicrobial, and immunomodulatory activity. 
In addition, in the analysis of the compounds of the ethanolic extract of $C$. pulverulentus, stigmasterol with TR of 46.33 and sitosterol with TR of 48.16 were identified, to which anti-inflammatory activity has been attributed (Liu et al., 2019). In previous studies, stigmasterol and sitosterol have been identified in an ethanolic extract of $C$. pulverulentus and could be responsible for the anti-inflammatory activity attributed to this species (Alonso-Castro et al. 2016).

\section{Determination of the antimicrobial activity of the Ethanolic Extract (E.E.) of C. pulverulentus}

C. pulverulentus is used in traditional medicine to treat "bad urine", a disease with symptoms that suggest a urinary tract infection (UTI). UTIs are caused by Enterobacteriaceae, the most frequent being Escherichia coli, Klebsiella pneumoniae and Proteus mirabilis that colonize the urinary tract causing a variety of symptoms compatible with "urine disease". In addition to Enterobacteriaceae, Staphylococcus aureus, S. epidermidis, S. saprophyticus and Enterococcus faecalis are also etiological agents of UTIs.

To determine the antimicrobial effect of C. pulverulentus, the E.E. against five bacteria, 3 Gram negative Escherichia coli and Klebsiella pneumoniae, related to bad urine; and Aeromonas hydrophila, which has also been reported as an etiologic agent in the urine of patients with cystitis and asymptomatic bacteriuria (Tena et al. 2007). It was also evaluated against 2 Gram positive Enterococcus faecalis and Bacillus sp.

For evaluation, filter paper discs were impregnated with $10 \mu \mathrm{g}$ of the E.E. and were placed on a lawn of bacteria inoculated on the MH agar. The results show that the E.E. of $C$. pulverulentus forms a growth inhibition halo on the plates where the two Gram positive bacteria, E. faecalis and Bacillus sp., respectively, were inoculated. The results show that the E.E. has significant activity against Bacillus sp, generating a halo of $16 \pm 0.06 \mathrm{~cm}$, this value is close to the established value $(20 \mathrm{~mm})$, by the CLSI with which it is indicated that the microorganism presents intermediate sensitivity to E.E. of $C$. pulverulentus. Regarding the effect against $E$. faecalis, E.E. generates a halo of $7 \pm$ $0 \mathrm{~mm}$;
However, this value has no clinical significance and is classified as resistance of the bacteria to E.E. of $C$. pulverulentus. Regarding Gram negative bacteria, no growth inhibition was observed in any of the evaluated species.

\section{Determination of the Anti-Quorum Sensing Activity of E.E. by C. pulverulentus}

The quorum sensing (QS) is the communication system in most bacterial species, it regulates the expression of genes involved in pathogenicity and virulence at the transcriptional level (Oliveiro et al., 2011). In Gram negative bacteria, QS is mediated by inducing molecules called acyl-homoserin lactones (AHL) that are produced in response to population density and are specific for each species of microorganism (Oliveiro et al., 2011).

Currently, QS is considered one of the therapeutic targets to control infections caused by Gram-negative bacteria (Oliveiro et al., 2011). For this reason, the search for QS inhibitor compounds is carried out in extracts, essential oils and pure compounds.

The most widely used model is Chromobacterium violaceum CV026, which produces a pigment called violacein. In this work, the effect of E.E. to determine if it possesses metabolites capable of blocking the QS mechanism in C. violaceum CV026 by inhibiting the synthesis of violacein.

The results obtained show that the production of violacein is not affected in the presence of E.E., indicating that the extract of $C$. pulverulentus does not have anti-QS compounds. However, the E.E. has a growth inhibitory effect at a dose of $10 \mu \mathrm{g} / \mathrm{disc}$, generating a halo of inhibition of $12 \mathrm{~mm}$ in the plate inoculated with $C$. violaceum $\mathrm{CV} 026$ 


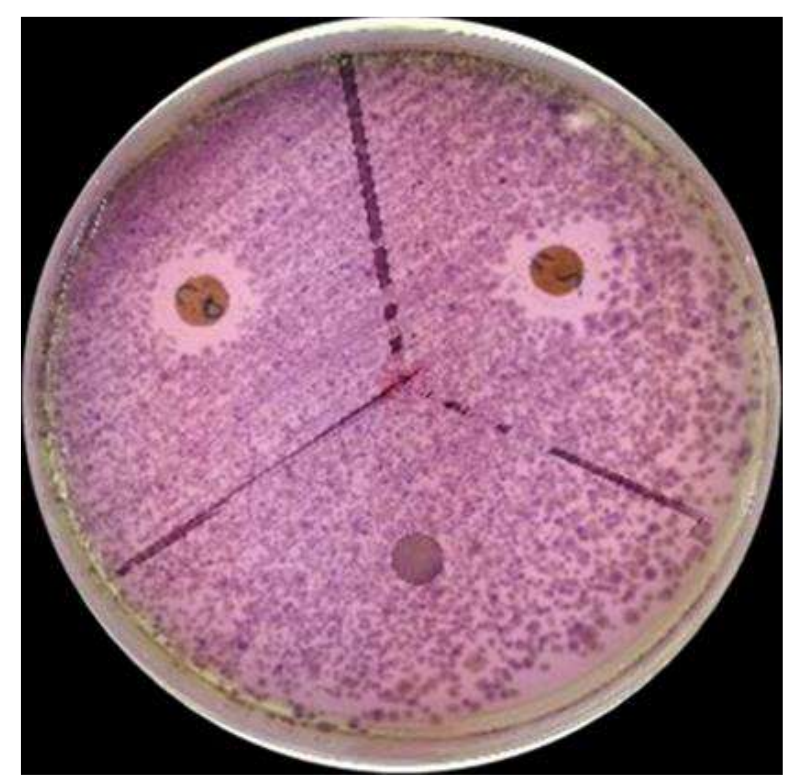

Figure 1 Effect of E.E. against C. violaceum CV026. All tests were done in triplicate

Fractionation of the Ethanolic Extract of C. pulverulentus

Once the inhibitory effect of E.E. against Bacillus sp., E. faecalis and $C$. violaceum CV026, the crude extract of $C$. pulverulentus was fractionated, in order to isolate and / or purify the metabolite with inhibitory activity. To isolate the compounds present in the E.E. of $C$. pulverulentus, the extract was brought to total dryness and the dry residue was fractionated with solvents of increasing polarity. 6 fractions were obtained in which the partitioning of the compounds present in the E.E. The compounds of E.E. were distributed in each fraction according to the polarity of the solvent used

The organic fractions were concentrated to dryness to obtain the residue, they were weighed and the yield was determined (Table 2).

\begin{tabular}{|l|c|r|}
\hline Fraction & Weight & Performance \% \\
\hline Hexanic & $0.4651 \mathrm{~g}$ & $0.4651 \%$ \\
\hline Chloroform & $0.0180 \mathrm{~g}$ & $0.0180 \%$ \\
\hline AceOEt & $0.0090 \mathrm{~g}$ & $0.0090 \%$ \\
\hline Acetone & $0.0128 \mathrm{~g}$ & $0.0128 \%$ \\
\hline Ethanolic & $0.1294 \mathrm{~g}$ & $0.1294 \%$ \\
\hline Methanolic & $0.3054 \mathrm{~g}$ & $0.3054 \%$ \\
\hline
\end{tabular}

Table 2. Yield of organic fractions obtained from E.E*. * Yield based on $100 \mathrm{~g}$ dry weight of the plant

\section{Antimicrobial activity of the organic fractions obtained from E.E.}

To determine the effect of the organic fractions, $30 \mu \mathrm{g}$ per disk were used to make the comparison with the effect of the reference antibiotic (Kanamycin).
It was tested against the bacteria from the first screen to identify if the fractions have an effect. The results obtained show that the hexane, chloroformic, AceOEt and acetonic fractions are inactive against the bacteria evaluated. However, the ethanolic and methanolic fractions generate a concentrationdependent halo of inhibition. In the case of Bacillus sp. the ethanolic fraction generates a halo of $8 \pm 0 \mathrm{~mm}$, while the methanolic fraction $15 \pm 0.5 \mathrm{~mm}$, indicating that the bioactive compound of E.E. is in the last fraction. In $E$. faecalis, an inhibition halo similar to that generated by E.E. complete, which according to CLSI indicates that the bacterium has resistance to the extract (Table 3).

\begin{tabular}{|l|r|r|r|}
\hline \multicolumn{1}{|c|}{ Bacterium } & \multicolumn{3}{c|}{ Fraction / Inhibition mm } \\
& EtOH & MeOH & Control \\
\hline Escherichia coli & 0 & 0 & 20 \\
\hline Klebsiella pneumoniae & 0 & 0 & 20 \\
\hline Aeromonas hydrophila & 0 & 0 & 20 \\
\hline Enterococcus faecalis & $7 \pm 0$ & $6 \pm 0$ & 15 \\
\hline Bacillus sp. & $8 \pm 0$ & $15 \pm 0.5$ & 19 \\
\hline $\begin{array}{l}\text { Chromobacterium } \\
\text { violaceum CV026 }\end{array}$ & 0 & $12 \pm 0$ & 0 \\
\hline Kanamycin control & \multicolumn{3}{|c|}{$\begin{array}{l}\text { Bacteria-dependent inhibition } \\
\text { according to international } \\
\text { standards (BSAC, 2013). }\end{array}$} \\
\hline
\end{tabular}

Table 3 Antimicrobial effect of Costus pulverulentus fractions at $30 \mu \mathrm{g} /$ disc (Concentration established for kanamycin discs, which is the reference antibiotic)

\section{Open Column Chromatography of the Methanolic Fraction}

Once the bioactive fraction had been identified, it was separated by open column chromatography. $200 \mathrm{mg}$ of the methanolic fraction were used and eluted with a polarity gradient with the Hexane: AceOEt: $\mathrm{MeOH}$ solvent system. 32 (F1-F32) fractions were obtained and brought to dryness on the Rotavapor R-100, the fractions were resuspended in methanol and analyzed by TLC. The process was repeated 10 times obtaining the same pattern of color and bands, by TLC.

\section{Antimicrobial Activity of the Fractions (F1- F32)}

To determine the antimicrobial activity of the 32 fractions, $10 \mu \mathrm{g}$ of fraction per disc were placed and evaluated against microorganisms that previously showed greater sensitivity to the methanolic fraction, Bacillus sp.

RAMIRO-BAUTISTA, Luis Rodrigo, HERNÁNDEZ-MORALES Alejandro, CARRANZA-ÁLVAREZ, Candy and MALDONADOMIRANDA, Juan José. Antibacterial activity of Costus pulverulentus (Costaceae) C. Presl. Journal of Natural and Agricultural Sciences. 2020 
The results obtained show that Fraction 8 (F8) generates an inhibition halo of $18 \pm 0 \mathrm{~mm}$ in the culture of Bacillus sp., Indicating that F8 possesses it or the metabolites responsible for the inhibitory effect generated by the methanolic fraction. The rest of the fractions did not show an inhibitory effect at the dose evaluated.

\section{Antimicrobial activity against clinically important microorganisms}

Once the F8 was obtained, inhibition tests were carried out against bacteria of priority importance according to the World Health Organization. For this, the guidelines established by the CLSI (Cos, Vlietinck, Berghe, and Maes, 2006; Balouiri, Sadiki, and Ibnsouda, 2016) were used. $30 \mu \mathrm{g}$ of F8 per disc were used and evaluated against representative bacteria of each microbial group (Table 4).

\begin{tabular}{|c|c|c|c|}
\hline \multirow[t]{2}{*}{ Group } & \multirow[t]{2}{*}{$\begin{array}{c}\text { Representative } \\
\text { bacteria }\end{array}$} & \multicolumn{2}{|c|}{$\begin{array}{l}\text { Inhibition } \\
\text { (mm) }\end{array}$} \\
\hline & & F8 & $\mathbf{K} \mathbf{m} *$ \\
\hline \multirow[t]{3}{*}{$\begin{array}{l}\text { Gram-positive } \\
\text { cocci }\end{array}$} & $\begin{array}{l}\text { Staphylococcus } \\
\text { aureus } \quad \text { ATCC } \\
29213\end{array}$ & $18 \pm 0$ & 19 \\
\hline & $\begin{array}{l}\text { Staphylococcus } \\
\text { aureus } O x^{R}\end{array}$ & $\begin{array}{l}18 \pm 0 \\
(\mathrm{Het})\end{array}$ & 19 \\
\hline & $\begin{array}{l}\text { Staphylococcus } \\
\text { epidermidis }\end{array}$ & 0 & 25 \\
\hline \multirow[t]{3}{*}{$\begin{array}{l}\text { Non-encapsulated } \\
\text { Enterobacteria }\end{array}$} & $\begin{array}{ll}\text { Escherichia } & \text { coli } \\
\text { ATCC } 15597 & \end{array}$ & 0 & 20 \\
\hline & $\begin{array}{l}\text { Escherichia coli } \\
\text { BLEE + }\end{array}$ & 0 & 20 \\
\hline & $\begin{array}{l}\text { Escherichia coli } \\
\text { BLEE - }\end{array}$ & 0 & 20 \\
\hline $\begin{array}{l}\text { Encapsulated } \\
\text { Enterobacteria }\end{array}$ & $\begin{array}{l}\text { Klebsiella } \\
\text { pneumoniae ATCC } \\
22895\end{array}$ & 0 & 20 \\
\hline No enterobacteria & $\begin{array}{l}\text { Pseudomonas } \\
\text { aeruginosa ATCC } \\
30298\end{array}$ & 0 & 22 \\
\hline \multicolumn{2}{|c|}{ Chromobacterium violaceum CV026 } & 0 & 0 \\
\hline
\end{tabular}

Table 4 Representative bacteria by group of microorganisms evaluated against fraction $8(\mathrm{~F} 8)$ of $\mathrm{C}$. pulverulentus

The results obtained show that F8 inhibits the development of $S$. aureus ATCC 29213 and S. aureus OxR and has no effect against the Gram negative bacteria evaluated. For the case of $S$. aureus ATCC 29213, a halo of $18 \pm 0 \mathrm{~mm}$ was obtained (Figure 2), which according to the CLSI criteria indicates sensitivity to F8. Regarding $S$. aureus OxR, F8 generates a halo of $18 \pm 0 \mathrm{~mm}$ in diameter (Figure 3); however, there is development of colonies within the halo suggesting that the strain has heterogeneous susceptibility.
Similar results were obtained with the antibiotic used as reference $(\mathrm{Km})$. In the case of Enterobacteriaceae and the Pseudomonas aeruginosa strain ATCC 30298, F8 does not exert an inhibitory effect. Regarding the effect against Gram negative bacteria, no significant effect was observed.

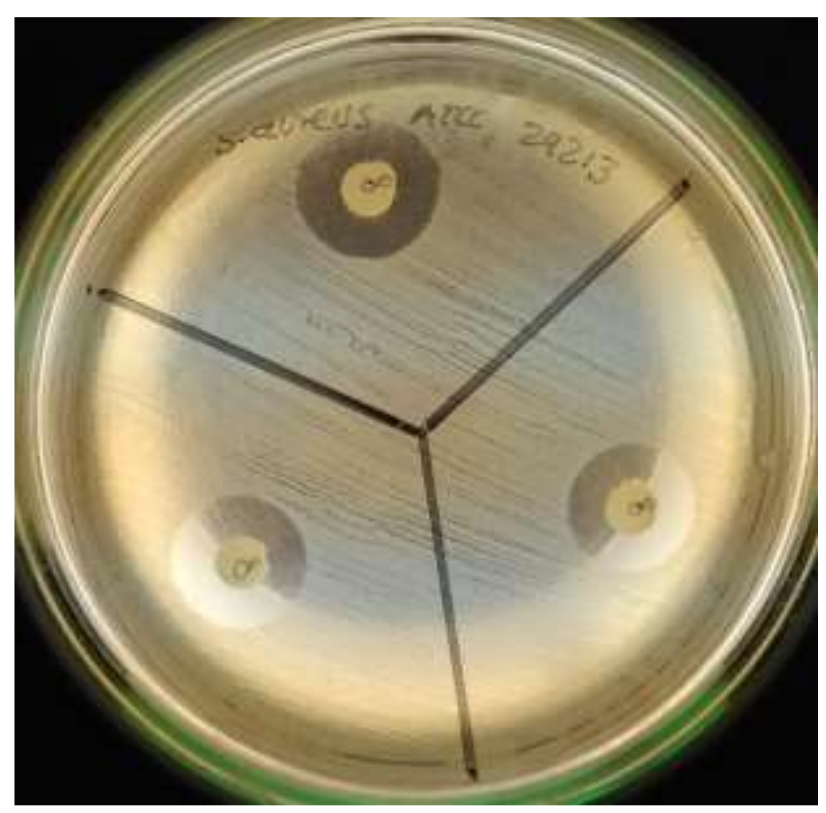

Figure 2 F8 inhibitory effect against: A) S. aureus ATCC 29213

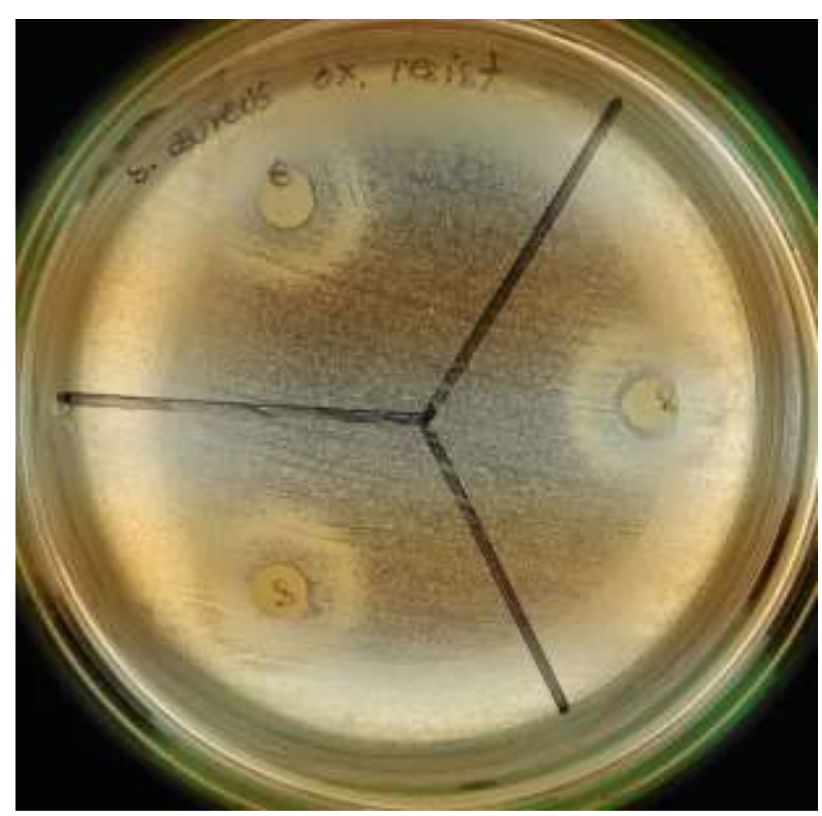

Figure 3 F8 inhibitory effect against: A) S. aureus oxacillin resistant (heterogeneous susceptibility)

\section{Analysis and characterization of F8}

The F8 was analyzed by GC-MS to determine the compounds responsible for the inhibitory activity. The chromatogram analysis revealed the presence of 16 peaks, of which 13 peaks $(81.25 \%)$ correspond to organic acids, 2 (12.5\%) were not identified in the NIST library and 1 $(6.25 \%)$ was identified as glycerol (Table 5).

RAMIRO-BAUTISTA, Luis Rodrigo, HERNÁNDEZ-MORALES, Alejandro, CARRANZA-ÁLVAREZ, Candy and MALDONADOMIRANDA, Juan José. Antibacterial activity of Costus pulverulentus (Costaceae) C. Presl. Journal of Natural and Agricultural Sciences. 2020 


\begin{tabular}{|l|l|l|l|}
\hline T.R & \multicolumn{1}{c}{ Area } & \multicolumn{1}{c|}{ AR } \\
\% & \multicolumn{1}{|c|}{ Compound } \\
\hline 12.47 & 182229996 & 3.18 & Lactic acid \\
\hline 12.89 & 49836550 & 0.87 & Hydroxyacetic acid \\
\hline 18.86 & 2194509791 & 38.33 & Glycerol \\
\hline 19.39 & 32683803 & 0.57 & Maleic Acid \\
\hline 19.64 & 344369982 & 6.02 & Succinic acid \\
\hline 20.29 & 53985329 & 0.94 & Glyceric acid \\
\hline 20.49 & 14528588 & 0.25 & Fumaric Acid \\
\hline 20.95 & 20439199 & 0.36 & NI \\
\hline 22.93 & 72596375 & 1.27 & $\begin{array}{l}\text { 3,4-Dihydroxy } \\
\text { butanoic acid }\end{array}$ \\
\hline 24.32 & 55911259 & 0.98 & Malic Acid \\
\hline 27.25 & 88872730 & 1.55 & $\begin{array}{l}\text { P-Hydroxy benzoic } \\
\text { acid }\end{array}$ \\
\hline 30.38 & 1158551128 & 20.24 & Vanilic acid \\
\hline 30.81 & 101690192 & 1.78 & $\begin{array}{l}\text { P-Cumaric acid } \\
\text { isomer 1 }\end{array}$ \\
\hline 30.99 & 16801180 & 0.29 & Azelaic Acid \\
\hline 32.45 & 29039520 & 0.51 & NI \\
\hline 33.86 & 1309135295 & 22.87 & $\begin{array}{l}\text { P-Cumaric } \\
\text { isomer 2 }\end{array}$ \\
\hline
\end{tabular}

Table 5 Chromatographic profile of F8 $N I=$ Compound not identified in the database

Among the most abundant compounds, glycerol is found in $38.33 \%$ relative abundance. Glycerol at concentrations of 50 and $80 \%$ has been shown to alter the viability of $P$. aeruginosa, Staphylococcus sp., Bacillus sp., This effect depends on the concentration and the exposure time (Saegeman et al. 2008). Among the organic acids identified, the most abundant are p-coumaric acid in $24.65 \%$ and vanilic acid in $20.24 \%$; these belong to the group of polyphenols, and could be responsible for the antimicrobial effect of F8 against $S$. aureus ATCC 29213 and $S$. aureus OxR (heterogeneous). In addition, a third polyphenol was identified, p-hydroxybenzoic acid, which could exert a synergistic effect with the major acids in F8.

\section{Antibacterial effect of p-coumaric acid and vanillic acid}

To determine the effect of the major F8 compounds, p-coumaric acid (Sigma C9008) and vanillic acid (Sigma 94770) were obtained from Sigma Aldrich and the antimicrobial activity was evaluated by plate microdilution. The MIC of p-coumaric acid and vanillic acid against S. aureus ATCC 29213 was determined because it was the bacteria most sensitive to F8.
To determine the potential of the pure compounds, the analysis included the representative bacteria of each group according to $\mathrm{WHO}$, the non-capsulated enterobacterium $E$. coli, the capsulated enterobacterium $K$. pneumoniae and $P$. aeruginosa that does not belong to the enterobacteria. In addition, the effect was evaluated against $S$. epidermidis, Proteus mirabilis and Citrobacter freundii. The results obtained show that p-coumaric acid has an antimicrobial effect against $S$. aureus, $S$. epidermidis, $P$. aeruginosa, E. coli, Citrobacter freundii and $K$. pneumoniae (Figure 4); while vanillic acid does not show an inhibitory effect at the concentrations evaluated (Table 6).

In order to determine if the combination of acids could enhance the antimicrobial activity, mixtures of p-coumaric acid with vanillic acid were made in a ratio of 1: 0.88 (The relationship is based on the results obtained from fraction 8 in the gas chromatography). Similar doses to individual compounds were evaluated. The results obtained showed that the inhibition pattern was not enhanced with the mixture of compounds. On the contrary, the effect in mixing decreased, because the amount of $\mathrm{p}$ coumaric acid was reduced.

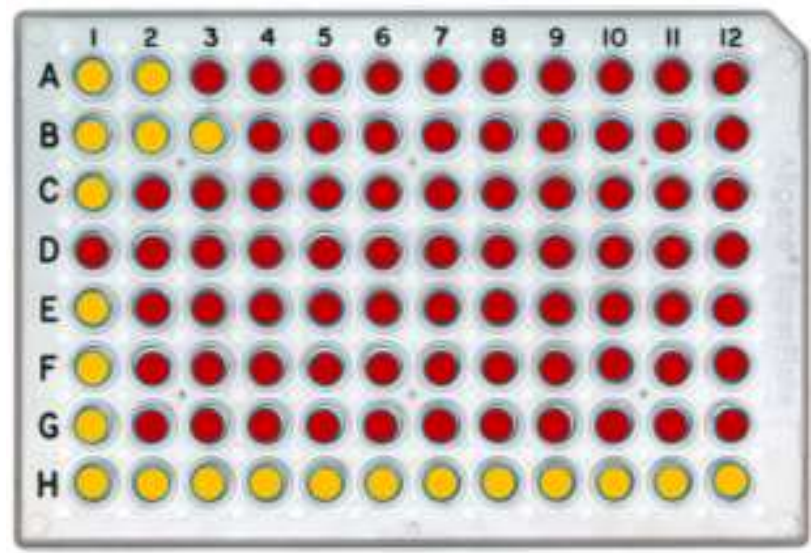

Figure 4.Rows with $\mathrm{MH}$ medium were inoculated with A) $P$. aeruginosa, B) S. aureus, C) E. coli, D) P. mirabilis, E) $S$. epidermidis, $F$ ) C. freundii, $G) K$. pneumoniae, $H$ ) Negative control, $\mathrm{MH}$ medium. In each column the concentration of p-coumaric acid 1) $1000 \mu \mathrm{g} / \mathrm{mL}$, 2) 500 $\mu \mathrm{g} / \mathrm{mL}$, 3) $250 \mu \mathrm{g} / \mathrm{mL}$, 4) $125 \mu \mathrm{g} / \mathrm{mL}$, 5) $62.5 \mu \mathrm{g} / \mathrm{mL}$, 6) $31.25 \mu \mathrm{g} / \mathrm{mL}$, 7) $15.62 \mu \mathrm{g} / \mathrm{mL}$, 8) $7.82 \mu \mathrm{g} / \mathrm{mL}$, 9) 3.90 $\mu \mathrm{g} / \mathrm{mL}, 10) 1.95 \mu \mathrm{g} / \mathrm{mL}$, 11) $0.97 \mu \mathrm{g} / \mathrm{mL}$, 12) $0 \mu \mathrm{g} / \mathrm{mL}$. The well in red color indicates bacterial activity by reduction of tetrazolium chloride. 


\begin{tabular}{|l|r|r|r|}
\hline \multicolumn{1}{|c|}{ Microorganism } & \multicolumn{2}{c|}{ PMI $(\mu \mathrm{g} / \mathrm{mL})$} & \\
& $\begin{array}{c}\text { Poumaric } \\
\text { acid }\end{array}$ & $\begin{array}{c}\text { Vanillic } \\
\text { acid }\end{array}$ & $\begin{array}{c}\text { Acid } \\
\text { mixture }\end{array}$ \\
\hline $\begin{array}{l}\text { P. aeruginosa ATCC } \\
\text { 30298 }\end{array}$ & 500 & $>1000$ & $>1000$ \\
\hline $\begin{array}{l}\text { S. aureus ATCC } \\
29213\end{array}$ & 250 & $>1000$ & $>1000$ \\
\hline E. coli ATCC 15597 & 1000 & $>1000$ & $>1000$ \\
\hline P. mirabilis & $>1000$ & $>1000$ & $>1000$ \\
\hline S. epidermidis & 1000 & $>1000$ & $>1000$ \\
\hline C. freundii & 1000 & $>1000$ & $>1000$ \\
\hline K. pneumoniae & 1000 & $>1000$ & $>1000$ \\
\hline
\end{tabular}

Table 6 Minimum inhibitory concentration

\section{Toxic activity against A. salina}

Artemia salina is one of the most valuable test organisms available for toxicity testing. Due to the speed, convenience and low cost of Artemiabased assays, the different extracts and organic fractions of $C$. pulverulentus were evaluated for toxicity. The results show that there is no toxic effect of the complete extract (750-30000 ppm), methanolic fraction (375-15000 ppm) and fraction 8 (25-1000 ppm) on nauplii of $A$. salina (Table 7) for the toxicity test acute in a 24-hour period (Rajabi, 2015).

\begin{tabular}{|c|c|c|c|}
\hline $\begin{array}{l}\text { Complete } \\
\text { extract } *\end{array}$ & $\begin{array}{l}\text { Methanolic } \\
\text { fraction * }\end{array}$ & {$[\mathrm{F} \mathrm{8}]^{*}$} & $\begin{array}{c}\text { Mortality } \\
(\%)\end{array}$ \\
\hline 750 & 375 & 25 & 0 \\
\hline 1500 & 750 & 50 & 0 \\
\hline 3000 & 1500 & 100 & 0 \\
\hline 7500 & 3750 & 250 & 0 \\
\hline 15000 & 7500 & 500 & 0 \\
\hline 30000 & 15000 & 1000 & 0 \\
\hline \multicolumn{3}{|c|}{ Saline solution control } & 0 \\
\hline \multicolumn{3}{|c|}{ Saline + solvent control } & 0 \\
\hline
\end{tabular}

Table 7 Toxicity test of E.E of Costus pulverulentus fractions on Artemia salina. * Concentrations expressed in $\operatorname{ppm}(\mu \mathrm{g} / \mathrm{mL})$

\section{Discussion}

Studies on C. pulverulentus have focused mainly on its distribution and biology (Guzmán, 2015; Sytsma et al., 1985). However, there are few studies of the biological and chemical activity of the plant. Regarding the pharmacological activity, it has been shown that the Ethanolic Extract of the stems of $C$. pulverulentus has cytotoxic activity against the PC3 prostate cancer cell line, anti-inflammatory and antinociceptive activity in mouse models. Likewise, it has been shown that it does not exert toxic effects in the evaluated models (AlonsoCastro et al., 2016).
With regard to phytochemistry, studies have focused on the characterization of the Ethanolic Extract of the stems in which the presence of organic acids and sterols has been identified (Alonso-Castro et al., 2016), many of which possess antinociceptive, antiinflammatory, antiproliferative and antimicrobial activity (Valerio and Awad, 2011; Liu et al., 2019; Santos et al., 2013; Walker et al., 2017; Novotny et al., 2017).

In the Huasteca Potosina, $C$. pulverulentus (Costaceae) is used in traditional medicine for the treatment of a condition colloquially called urine disease, whose symptoms correspond to a urinary tract infection (UTI) (Andreu et al., 2011) . UTIs are a serious public health problem and are caused by a variety of pathogens, commonly Escherichia coli, Klebsiella pneumoniae, Proteus mirabilis, Enterococcus faecalis, and Staphylococcus saprophyticus, affecting approximately 150 million people each year worldwide ( FloresMireles et al., 2015).

The traditional use of $C$. pulverulentus (Costaceae) for the treatment of "bad urine" suggests that the plant possesses bioactive metabolites with antimicrobial activity. Therefore, in this work, the antibacterial activity of the plant was evaluated against bacterial strains that commonly cause UTIs. Additionally, the effect against bacterial species whose resistance to antibiotics makes it necessary to search for therapeutic alternatives was evaluated.

To carry out this study, the Ethanolic Extract (EE) of the stems of $C$. pulverulentus was elaborated, in order to identify the bioactive metabolite, and the antimicrobial effect against Escherichia coli, Klebsiella pneumoniae, Aeromonas hydrophila, Enterococcus faecalis was determined. and Bacillus sp. The results obtained show that E. faecalis and Bacillus sp. show moderate sensitivity to E.E. of $C$. pulverulentus, while Gram negative bacteria are resistant to the doses evaluated.

In most antimicrobial studies, Gram negative bacteria appear to show greater resistance to natural products compared to Gram positive bacteria. This fact could be related to the complexity of the membrane of Gram negative bacteria (de la Fuente-Salcido et al., 2015). 
In the case of this bacterial group, the alternative has been to search for bioactive metabolites with anti-quorum sensing activity (Olivero et al., 2011). Therefore, in this study, the anti-QS activity of E.E. of $C$. pulverulentus in the inhibition of the production of the pigment violacein in $C$. violaceum CV026. The results obtained showed that the production of violacein is not affected by E.E., indicating that the extract of $C$. pulverulentus does not have anti-QS compounds. However, it shows growth inhibitory effect of $C$. violaceum CV026 at a dose of $10 \mu \mathrm{g} / \mathrm{disc}$, generating a $12 \mathrm{~mm}$ inhibition halo in the inoculated plate.

The chemical characterization of the extract shows the presence of carbohydrates, organic acids and sterols, in a similar way to that previously reported (Alonso-Castro et al., 2016). Phenolic compounds were identified among organic acids, to which antimicrobial activity has been attributed (Creus, 2004). In this work, the evaluated doses of E.E. of $C$. pulverulentus exert moderate antimicrobial activity against $E$. faecalis, Bacillus sp. and C. violaceum CV026.

To determine the bioactive metabolite (s) responsible for the antimicrobial effect, the E.E. of $C$. pulverulentus (Costaceae) using solvents of different polarity (hexane, chloroform, ethyl acetate, acetone, ethanol and methanol) in order to purify and separate the compounds contained in the mixture, subsequently the antimicrobial activity of the fractions was determined. The results obtained show that the methanolic fraction preserves the antimicrobial activity against E. faecalis, Bacillus sp. and $C$. violaceum CV026, while the rest of the fractions did not show inhibitory effects. Results suggest that bioactive compounds are polar in nature.

The methanolic fraction was purified by column chromatography in order to obtain the bioactive metabolite responsible for the antimicrobial activity. 32 fractions were obtained and antimicrobial activity was evaluated. The results obtained showed that only fraction 8 (F8) conserved the biocidal activity against Bacillus sp., Indicating that the bioactive metabolite is found in this fraction. Regarding $C$. violaceum CV026, none of the fractions showed an inhibitory effect, suggesting that the biocidal activity of F8 is due to the synergistic effect of the compounds present in it.
Additionally, F8 inhibits the development of S. aureus ATCC 29213 and $S$. aureus $\mathrm{OxR}$, however, at the doses evaluated it lacks an inhibitory effect against the Gram negative bacteria used in the study.

Analysis of F8 by GC-MS shows the presence of 16 peaks, indicating that column chromatography does not resolve the metabolites present in this fraction. According to the analysis, F8 mainly contains three compounds from the group of polyphenols, $\mathrm{p}$ coumaric, vanillic and p-hydroxybenzoic acids, which could be responsible for the antimicrobial effect of F8 against S. aureus ATCC 29213 and S. aureus OxR.

To determine the individual effect of the compounds present in F8, the two major acids, p-coumaric acid and vanillic acid, were selected. The MIC for organic acids was determined by 1 : 2 dilutions according to Cos et al. (2009). The results showed that $\mathrm{p}$-coumaric acid has antimicrobial activity against $S$. aureus ATCC 29213 at a MIC of $250 \mu \mathrm{g} / \mathrm{mL}$. The effect of pcoumaric acid against $S$. aureus is controversial, because studies in this regard report different MIC doses from each other, which may be due to the technique used and the strains evaluated in the determinations. Alves et al. (2013) suggests that p-coumaric acid exerts antimicrobial activity against sensitive (MSSA) and methicillin resistant (MRSA) S. aureus at a MIC greater than $1000 \mu \mathrm{g} / \mathrm{mL}$, while Kozyra et al. (2019) found no activity of p-coumaric acid against the type strains of $S$. aureus ATCC 6538 and S. aureus ATCC 25923.

On the other hand, Krishna et al. (2014) shows that $200 \mu \mathrm{g}$ of $\mathrm{p}$-coumaric acid generate an inhibition halo in the development of $S$. aureus by means of disk diffusion tests. In $S$. epidermidis, a MIC of $1000 \mu \mathrm{g} / \mathrm{mL}$ was determined, similar to that previously reported for the strain type $S$. epidermidis ATCC 12228 (Kozyra et al. 2019), and lower than that reported by Alves et al. (2013) who suggest that the MIC for S. epidermidis is greater than 1000 $\mu \mathrm{g} / \mathrm{mL}$.

Regarding Gram negative bacteria, for $P$. aeruginosa ATCC 30298 a MIC of $500 \mu \mathrm{g} / \mathrm{mL}$ was determined. So far there are no reports where the activity of p-coumaric acid against this bacterium is determined. 
However, p-coumaric acid at $61.0 \mu \mathrm{M}$ has been shown to inhibit the development of Pseudomonas putida by 33\% (Rühl et al. 2009). Regarding the rest of the Gram negative microorganisms, a MIC of $1000 \mu \mathrm{g} / \mathrm{mL}$ was determined for $E$. coli ATCC 15597, C. freundii, $K$. pneumoniae, while $P$. mirabilis was the most resistant bacterium with a MIC greater than 1000 $\mu \mathrm{g} / \mathrm{mL}$. In previous studies, the antibacterial potential of p-coumaric acid against $E$. coli was demonstrated with a MIC of $1000 \mu \mathrm{g} / \mathrm{mL}$, similar to the dose obtained in this work (Alves et al. 2013).

In general, p-coumaric acid has been shown to exert antibacterial activity by significantly increasing the permeability of the outer membrane and the plasma membrane (Lou et al., 2012). Likewise, it has been suggested that it binds to bacterial genomic DNA to inhibit cellular functions (Lou et al. 2012). Due to its antibacterial properties, p-coumaric acid has been evaluated in food systems as a preservative agent and growth inhibitor of $S$. aureus, the main food contaminant (Stojković et al., 2013). Pcoumaric acid at concentrations of 0.23 to 1.87 $\mu \mathrm{g} / \mathrm{mL}$ has been shown to inhibit in situ, in prepared chicken broth and pork, the growth of $S$. aureus for a period of $72 \mathrm{~h}$. In addition, the inhibitory effect of p-coumaric acid improves the organoleptic characteristics of food, which shows its usefulness as a preservative and flavor enhancer for the food industry (Stojković et al. 2013).

Regarding vanillic acid, it was determined that the concentrations used did not inhibit the development of the Gram-positive microorganisms evaluated, suggesting that the MIC is higher than $1000 \mu \mathrm{g} / \mathrm{mL}$. The doses determined in this study are similar to those reported by Kozyra et al. (2019) for $S$. epidermidis ATCC 12228, who show that the MIC is greater than $1000 \mu \mathrm{g} / \mathrm{mL}$. On the other hand, it has been shown that vanillic acid does not inhibit the development of the type strains, S. aureus ATCC 6538 and S. aureus ATCC 25923 (Kozyra et al. 2019). However, Alves et al. (2013) demonstrated a MIC of $1000 \mu \mathrm{g} / \mathrm{mL}$ and $500 \mu \mathrm{g} / \mathrm{mL}$ of vanillic acid for sensitive (MSSA) and methicillin-resistant (MRSA) $S$. aureus, respectively. S. aureus MRSA is a causative agent of difficult-to-treat nosocomial infections due to the emergence of resistant strains and the limited availability of efficient antibiotics (Chambers 2001).
Therefore, it is necessary to search for alternatives to control this microorganism. In this sense, it has been shown that vanillic acid acts as an inhibitor of beta-lactam-resistant peptidoglycan PBP2a MecA transpeptidase in $S$. aureus MRSA (Alves et al. 2013), being an excellent alternative for antibacterial treatment. Despite the fact that in this study no significant antibacterial activity of vanillic acid was found against the available strains of $S$. aureus, our results show that $C$. pulverulentus is a potential source of vanillic acid that can be used for the treatment of infections caused by MRSA.

Regarding Gram negative bacteria, the MIC for vanillic acid is higher than $1000 \mu \mathrm{g} /$ $\mathrm{mL}$, these results differ from the inhibitory effect reported by Alves et al. (2013) with a MIC of $1000 \mu \mathrm{g} / \mathrm{mL}$ for E. coli and P. mirabilis (Alves et al. 2013).

Additionally, a mixture of p-coumaric acid and vanillic acid was made in a proportion similar to that identified in F8. The mixture was evaluated in order to determine if the combination of compounds enhanced antimicrobial activity. However, the activity decreased because the concentration of $p$ coumaric acid was reduced. This suggests that $\mathrm{p}$ coumaric acid is primarily responsible for the antibacterial activity of F8.

\section{Conclusions}

The complete extract and ethanolic fraction of Costus pulverulentus, in addition to the activities previously reported, shows the ability to inhibit the growth of bacteria of medical importance, mainly on S. aureus. In the subsequent column fractionation, only fraction number 8 maintains activity against Bacillus sp. and $S$. aureus ATCC 29213 and resistant Ox in concentrations of 30 $\mu \mathrm{g} /$ disc, showing a medium susceptibility according to the CLSI criteria. After gas chromatography coupled with mass spectrometry, the antimicrobial activity is attributed to the major metabolites of fraction 8, which are vanillic acid and p-coumaric acid, which are polar chemical compounds from the secondary metabolism of the plant and which can be classified as phenolic compounds. The microdilution plate test shows that the compound with the highest activity is pcoumaric acid on $S$. aureus ATCC 29213 at a concentration of $250 \mathrm{mg} / \mathrm{L}$. 
The evidence allows us to suggest the absence of acute toxicity of the complete extract and the fractions evaluated in the standardized test with A. salina.

The Ethanolic Extract and the fractions obtained from $C$. pulverulentus did not show anti-QS activity on $C$. violaceum CV026 at concentrations of 10 and $30 \mu \mathrm{g} /$ disc, however, if growth inhibition is observed despite the fact that the strain has genes resistance to kanamycin, the antibiotic used as a control.

\section{References}

Alonso-Castro, A. J., Dominguez, F., Morales, J., y Carranza-Alvarez, C. (2015). Plants used in the traditional medicine of Mesoamerica (Mexico and Central America) and the Caribbean for the treatment of obesity. Journal of ethnopharmacology. 175. 10.1016/j.jep.2015.09.029.

Alonso-Castro, A. J., Zapata-Morales, J. R., González-Chávez, M. M., Carranza-Álvarez, C., Hernández-Benavides, D. M., y HernándezMorales, A. (2016). Pharmacological effects and toxicity of Costus pulverulentus C. Presl (Costaceae). Journal of ethnopharmacology, 180, 124-130.

Alves, M. J., Ferreira, I. C., Froufe, H. J., Abreu, R. M. V., Martins, A., y Pintado, M. (2013). Antimicrobial activity of phenolic compounds identified in wild mushrooms, SAR analysis and docking studies. Journal of applied microbiology, 115(2), 346-357.

Andreu, A., Cacho, J., Coira, A., y Lepe, J. A. (2011). Diagnóstico microbiológico de las infecciones del tracto urinario. Enfermedades Infecciosas y Microbiología Clínica, 29(1), 5257.

Balouiri , M., Sadiki, M., y Ibnsouda, S. K. (2016). Methods for in vitro evaluating antimicrobial activity: A review. Journal of Pharmaceutical Analysis, 71-79.

Balunas, M., y Kinghorn, A. (2005). Drug discovery from medicinal plants. Life Sciences, 78, 431-441.

Bansal, D., Malla, N. y Mahajan, R. C. (2006). Drug resistance in amoebiasis. Indian Journal of Medical Research 123, 115-118.
BSAC. (2013). BSAC Methods for Antimicrobial Susceptibility Testing. British Society for Antimicrobian Chemotherapy.

Calderon-Rojas, G., y Aguilar-Ulalde, L. (2016). Resistencia antimicrobiana: Microorganismos más resistentes y antinbióticos con menor actividad. REVISTA MEDICA DE COSTA RICA Y CENTROAMERICA, LXXIII (621), 757-763.

Chambers, H. F. (2001). The changing epidemiology of Staphylococcus aureus?. Emerging infectious diseases, 7(2), 178.

Cohen, F. L., y Tartasky, D. (1997). Microbial resistance to drug therapy: a review. American Journal of Infection Control, 51-64.

Cos, P., Vlietinck, A. J., Berghe, D. V., y Maes, L. (2006). Anti-infective potential of natural products: how to develop a stronger in vitro "proof-of-concept". Journal of Ethnopharmacology (106), 209-302.

Coyle, M. B. (2005). Manual of Antimicrobial Susceptibility Testing. American Society for Microbiology.

Creus, E. G. (2004). Compuestos fenólicos. Un análisis de sus beneficios para la salud. O F F A R M, 23 (6), 80-84.

De la Fuente-Salcido, N. M., Villarreal-Prieto, J. M., Díaz León, M. A., y García Pérez, A. P. (2015). Evaluación de la actividad de los agentes antimicrobianos ante el desafío de la resistencia bacteriana. Revista mexicana de ciencias farmacéuticas, 46(2), 7-16. Recuperado en 15 de noviembre de 2020, de http://www.scielo.org.mx/scielo.php?script=sci _arttext\&pid=S1870-

01952015000200007\&lng=es\&tlng=es

Flores-Mireles, A. L., Walker, J. N., Caparon, M., y Hultgren, S. J. (2015). Urinary tract infections: epidemiology, mechanisms of infection and treatment options. Nature reviews microbiology, 13(5), 269-284.

Guzmán Q, J. A. (2015). Ecological advantage of leaf heteroblasty in Costus pulverulentus (Costaceae). Botany, 93(3), 151-158.

RAMIRO-BAUTISTA, Luis Rodrigo, HERNÁNDEZ-MORALES Alejandro, CARRANZA-ÁLVAREZ, Candy and MALDONADOMIRANDA, Juan José. Antibacterial activity of Costus pulverulentus (Costaceae) C. Presl. Journal of Natural and Agricultural Sciences. 2020 
Kozyra, M., Komsta, Ł., y Wojtanowski, K. (2019). Analysis of phenolic compounds and antioxidant activity of methanolic extracts from inflorescences of Carduus sp. Phytochemistry letters, 31, 256-262.

Liu R., Hao, D., Xu, W., Li, J., Li, X., Shen, D., Sheng, K., Zhao, L., Xu, W., Gao, Z., et al. (2019). $\beta$-Sitosterol modulates macrophage polarization and attenuates rheumatoid inflammation in mice. Pharm Biol. 57: 161-168. doi:10.1080/13880209.2019.1577461

Lou, Z., Wang, H., Rao, S., Sun, J., Ma, C., y Li, J. (2012). p-Coumaric acid kills bacteria through dual damage mechanisms. Food control, 25(2), 550-554.

Novotny L, ME Abdel-Hamid, L Hunakova. (2017). Anticancer potential of $\beta$-Sitosterol. Int J Clin Pharmacol Pharmacother. https://doi.org/10.15344/2456-3501/2017/129

Olivero, J. T., Pájaro, N. P., y Stashenko, E. (2011). Antiquorum sensing activity of essential oils isolated from different species of the genus Piper. Vitae, Revista de la Facultad de Química Farmacéutica, 18(1), 77-82.

OMS. (2013). Estrategia de la OMS sobre medicina tradicional 2014-2023. Organización Mundial de la Salud.

OMS. (2017). ¿Qué es la resistencia a los antimicrobianos? Preguntas y respuestas en línea. Obtenido de Organización mundial de la salud: https://www.who.int/features/qa/75/es/

OMS. (2016). Resistencia a los antimicrobianos. Obtenido de Organización Mundial de la Salud: http://www.who.int/mediacentre/factsheets/fs 19 4/es/

Rajabi, S., Ramazani, A., Hamidi, M., y Naji, T. (2015). Artemia salina as a model organism in toxicity assessment of nanoparticles. DARU Journal of Pharmaceutical Sciences, 23(20).

Rühl, J., Schmid, A., y Blank, L. M. (2009). Selected Pseudomonas putida strains able to grow in the presence of high butanol concentrations. Appl. Environ. Microbiol., 75(13), 4653-4656.
Saegeman, V., Ectors, N., Lismont, D., Verduyckt, B., Verhaegen, J. (2008). Short- and long-term bacterial inhibiting effect of high concentrations of glycerol used in the preservation of skin allografts. Burns: Journal of the International Society for Burn Injuries. 34. 205-11. 10.1016/j.burns.2007.02.009.

Santos CCdMP, MS Salvadori, VG Mota, LM Costa, AAC de Almeida, GAL de Oliveira, JP Costa, DP de Sousa, RM de Freitas, RN de Almeida. 2013. Antinociceptive and antioxidant activities of phytol in vivo and in vitro models. Neurosci J. 2013: 949452-949452. doi:10.1155/2013/949452

Stojković, D., Petrović, J., Soković, M., Glamočlija, J., Kukić-Marković, J., y Petrović, S. (2013). In situ antioxidant and antimicrobial activities of naturally occurring caffeic acid, pcoumaric acid and rutin, using food systems. Journal of the Science of Food and Agriculture, 93(13), 3205-3208.

Sytsma, K. J., y Pippen, R. W. (1985). Morphology and pollination biology of an intersectional hybrid of Costus (Costaceae). Systematic botany, 353-362.

Tena, D., González-Praetorius, A., Gimeno, C., Pérez-Pomata, M. T., y Bisquert, J. (2007). Infección extraintestinal por Aeromonas sp.: revisión de 38 casos. Enfermedades infecciosas y microbiología clínica, 25(4), 235-241.

Valerio M, AB Awad. 2011. $\beta$-Sitosterol downregulates some pro-inflammatory signal transduction pathways by increasing the activity of tyrosine phosphatase SHP-1 in J774A.1 murine macrophages. Int Immunopharmacol. 11: 1012-1017. doi:10.1016/j.intimp.2011.02.018

Walker CIB, SM Oliveira, R Tonello, MF Rossato, E da Silva Brum, J Ferreira, G Trevisan. 2017. Anti-nociceptive effect of stigmasterol in mouse models of acute and chronic pain. Naunyn Schmiedebergs Arch Pharmacol. 390: 1163-1172. doi:10.1007/s00210-017-1416-x 